\title{
Genotype variation in grain nutrient concentration in tropical maize grown during a rainy and a dry seaon
}

\author{
B Feil 1, R Thiraporn 2, G Geisler 3, P Stamp 1 \\ 1 Institute of Plant Sciences, ETH-Zentrum, Universitätstrasse 2, CH-8092 Zürich, Switzerland; \\ 2 Kasetsart University, Department of Plant Science, Bagkhen, Thailand; \\ ${ }^{3}$ Institut für Pflanzenbau und Pflanzenzüchtung der Universität Kiel, Olshausenstr, 40, D-2300 Kiel, Germany
}

(Received 20 March 1990; accepted 24 August 1990)

\begin{abstract}
Summary - A set of 12 tropical maize cultivars was screened for grain nitrogen, phosphorus, and potassium concentration (GNC, GPC and GKC). The experiments were conducted at the National Corn and Sorghum Research Centre, Farm Suwan, Pakchong, Thailand during a rainy and a dry season. The genotypic variability in GNC, GPC and GKC was considerable. There was no inverse relationship between grain yield and grain nutrient concentration. The hybrids KUH 2301 and KUH 2602 were identified as high yielding, high GNC cultivars. However, due to positive correlations between GNC and GPC, both cultivars exported much more phosphorus from the field than the high yielding low GNC cultivars, Pi hybrid 6181 and CP hybrid. The cultivation of the latter 2 should be recommended to Thai cash crop farmers as a means of reducing the need for large amounts of scarce and costly mineral fertilizers and because decreases in GNC, GPC and GKC are not necessarily a disadvantage for utilization in animal husbandry in developed countries.
\end{abstract}

maize / tropical cultivar / grain N concentration / grain P concentration / grain K concentration

\begin{abstract}
Résumé - Variation génotypique de la concentration des grains en éléments nutritifs chez des maïs tropicaux cultivés pendant une saison des pluies et une saison sèche. Un ensemble de 12 cultivars tropicaux de maïs a été étudié pour la teneur des grains en azote, phosphore et potassium (GNC, GPC et GKC). Les essais ont été conduits au National Corn and Sorghum Research Centre, Farm Suwan, Pakchong, Thaïlande, pendant une saison des pluies et une saison sèche. La variabilité génotypique des GNC, GPC et GKC a été considérable. Aucune relation n'a été observée entre rendements en grains et concentrations en nutriments dans les grains (fig 1a-f). Les hybrides KUH 2301 et KUH 2602 ont été identifiés comme cultivars à haut rendement et haut GNC (fig 1a, b). Mais, à cause d'une corrélation positive entre GNC et GPC (tableau II), tous 2 ont exporté hors du champ beaucoup plus de phosphore que les cultivars à haut rendement et bas GNC que sont Pi hybride 6181 et CP hybride. Aux agriculteurs thailandais produisant pour la commercialisation, la culture de ces 2 derniers devrait être recommandée comme moyen de réduire les besoins en engrais minéraux rares et chers. De plus une diminution des GNC, GPC et GKC n'est pas nécessairement désavantageuse pour l'alimentation animale dans les pays développés.
\end{abstract}

mais / cultivar tropical / concentration des grains en $N$ / concentration des grains en $P$ / concentration des grains en $K$

\section{INTRODUCTION}

For economical and ecological reasons, plant nutrients should be applied as efficiently as possible. Low concentrations of mineral nutrients in the grains can help to avoid wasting mineral fertilizers and polluting water.

A high protein content is an important dietary criterion of grain maize. Although both early and more recent investigations (Boyat et al, 1979, 1980) have shown genotypic variability in grain nitrogen concentration (GNC), breeding for high GNC has been neglected up to now. This is mainly due to the low economical value of high protein maize. Furthermore, there is a widespread assumption that improvement of GNC leads to decreases in grain yield (Glover and Mertz, 1987). Actually, inverse relationships between GNC and grain yield have sometimes been found (Gupta et al, 1975; Dudley et al, 1977). However, Eberhard (1977) and Kauffmann and Dudley (1979) could not confirm such a negative correlation. 
Whereas high concentrations of $\mathbf{N}$ in the grains are desirable, lower concentrations of phosphorus and potassium (GPC and GKC, respectively) may prove to be rewarding goals for plant breeders. Low accumulation of $P$ in maize kernels would reduce the content of phytate (Michael et al, 1980) which is thought to be responsible for mineral deficiency $(\mathrm{Ca}, \mathrm{Cu}, \mathrm{Zn})$ both in animals and in man (Maga, 1982). Furthermore, with an average utilization rate of only $30 \%$, phytate is a rather inefficient source of $P$ for monogastric animals and man. Additionally, nonutilized phytate-P cannot be recycled from manure, slurry or sludge if grain maize is grown as a cash crop. Therefore, from the nutrient efficiency and ecology point of view, it seems to be preferable to use maize cultivars with a low GPC and to add, if necessary, supplemental $P$ directly as inorganic salt. A decrease in GKC is also desirable because man and animals have low $K$ requirements.

Growing high-yielding cultivars with high GNC but low GPC and GKC would be especially profitable to third-world farmers for whom fertilizers are either unavailable or too expensive as compared to the prices paid for maize. In this study, a set of tropical maize cultivars was screened for genotypic variability in GNC, GPC and GKC with the goal of identifying high yielding nutrientefficient cultivars. Furthermore, the relationships between (1) grain yield and mineral nutrient enrichment in kernels and (2) GNC, GPC and $G K C$, were considered in order to determine possible incompatibilities between some breeding goals. During 2 extremely contrasting cropping periods (rainy and dry season) field experiments were conducted to obtain information about the stability of correlations and varietal differences.

\section{MATERIALS AND METHODS}

Both trials were carried out at the National Corn and Sorghum Research Centre, Farm Suwan, Pakchong, Thailand (latitude $14.5^{\circ} \mathrm{N}$ ).

\section{Plant material}

The plant material consisted of 12 tropical cultivars which were formerly or are currently used by Thai farmers: (1) Suwan I; (2) Suwan II; (3) Thai $\mathrm{O}_{2}$ Comp \#3; (4) Thai Comp \#3; (5) KUC 9; (6) TFE; (7) Guatemala DMR; (8) KUH 2301; (9) KUH 2602; (10) Pi hy- brid 6181; (11) Pacific hybrid; (12) CP hybrid. Cultivars (1) to (7) are open pollinated varieties, the others are hybrids. Apart from some commercial hybrids (Pi hybrid 6181, Pacific hybrid, CP hybrid) these cultivars originate from the national com breeding program of the Kasetsart University. The open pollinated cultivars are predominantly based on Caribbean and Mexican flint-dent sources. The grain of all cultivars is orangeyellow, the kernel type is mostly semi-flint and in a few cases, flint.

\section{Climatic and agronomic conditions}

The trials were sown on July 20,1985 (rainy season) and December 7, 1985 (dry season), respectively.

During the whole rainy season the maximum and minimum temperatures varied from $30^{\circ} \mathrm{C}$ during the day to $21^{\circ} \mathrm{C}$ during the night. The dry season trial had, at first, maximum temperatures of $27^{\circ} \mathrm{C}$ during the day and minimum temperatures of $16{ }^{\circ} \mathrm{C}$ during the night. However, during March and April, maximum day temperatures of $32{ }^{\circ} \mathrm{C}$ and minimum night temperatures of $27^{\circ} \mathrm{C}$ were reached.

During both seasons, plots were irrigated at weekly intervals when necessary. The soil type was a reddish brown latosol. The soil analysis of the $A_{p}$ horizon (depth $0-16 \mathrm{~cm}$ ) revealed the following values: water $\mathrm{pH}, 6.6 ; 2.5 \%$ organic matter; $\mathrm{P}$ (Bray II), 69 ppm; $\mathrm{K}$ (exchanged with $1 \mathrm{mmol}^{-1}$ ammonium acetate, $\mathrm{pH}$ $7.0), 133 \mathrm{ppm}$ (rainy season) and $\mathrm{pH} 7.5,2.6 \%$ organic matter, 92 ppm P and 175 ppm K (dry season). All treatments received $27 \mathrm{~kg}^{\circ h a^{-1}} P$ as TSP and 41 $\mathrm{kg} \cdot \mathrm{ha}^{-1}(\mathrm{~K})$ as $\mathrm{KCl}$. During both seasons, the nitrogen supply was $40 \mathrm{~kg} \mathrm{~N}$ given as $\left(\mathrm{NH}_{4}\right)_{2} \mathrm{SO}_{4}$ before sowing. The previous crop was maize. All plots consisted of 6 rows, spaced $75 \mathrm{~cm}$ apart and $5 \mathrm{~m}$ long. The plots were thinned to 5.3 plants $\cdot \mathrm{m}^{-2}$ at the 4 leaf stage. Weed was removed by hand. During both seasons, fungicides were sprayed against downy mildew. Eight plants from each plot were harvested at full maturity (about 20\% grain moisture). All samples were dried to constant weight in a convection oven at $105^{\circ} \mathrm{C}$. Each value presented in the figures was calculated from 12 replications which were randomized in a block design.

Plant and soil samples were analyzed in the Central Laboratories of the Kasetsart University.

\section{RESULTS}

Average grain yield was almost $40 \%$ higher during the dry season although 1000 kernel weights were rather similar during both seasons (table 1). In contrast to grain yield and biomass, harvest index (proportion of grain dry matter to total biomass) was affected only to a slight degree. During the rainy season, the maize plants developed considerably faster from emergence to silking 
Table I. Comparison of the rainy and the dry season trial (average values of 12 maize cultivars).

\begin{tabular}{lccc}
\hline & $\begin{array}{c}\text { Rainy } \\
\text { season }\end{array}$ & $\begin{array}{c}\text { Dry } \\
\text { season }\end{array}$ & $\begin{array}{c}\text { Standard } \\
\text { error }\end{array}$ \\
\hline Grain yield (g·pl-1) & 62.9 & 86.8 & 1.7 \\
1 000 kernel weight (g) & 252 & 264 & 3 \\
Biomass (g·pl-1) & 173.3 & 220.3 & 3.0 \\
Harvest index (\%) & 35.7 & 38.9 & 0.4 \\
Total N uptake (mg•pl-1) & 1951 & 1735 & 39 \\
N harvest index (\%) & 52.0 & 69.4 & 0.6 \\
Total P uptake (mg•pl-1) & 136 & 341 & 6 \\
P harvest index & 67.1 & 66.8 & 1.1 \\
Total K uptake (mg•pl-1) & 1342 & 2317 & 34 \\
K harvest index (\%) & 24.5 & 12.9 & 0.5 \\
Grain N (\%) & 1.67 & 1.38 & 0.02 \\
Grain P (\%) & 0.15 & 0.26 & 0.03 \\
Grain K (\%) & 0.53 & 0.34 & 0.01 \\
Days to silking & 46.5 & 66.5 & 0.02 \\
Days to black layer & 85.4 & 112.0 & 0.4 \\
\hline
\end{tabular}

and during grain growth. Total plant nutrient accumulation depended to a great extent on seasonal effects. In contrast to $\mathrm{N}$ uptake which was even higher, $P$ and $K$ accumulation was distinctly lower during the rainy season. Remarkably, nutrient harvest indices (proportion of grain nutrients to total amount of nutrients) did not respond uniformly to varying growing conditions. Contrasting reactions were observed in $\mathrm{K}$ and $\mathrm{N}$ harvest indices, whereas the $P$ harvest index remained more or less stable.

Grain nutrient concentrations were influenced by seasonal conditions. Enhanced GNC during the rainy season was associated with increases in GKC but with a decrease in GPC. The contrasting growing conditions of both seasons influenced the ranking of cultivars in grain yield to a high degree. The poor correlation between the varietal productivity during the rainy and the dry season $(r=+0.31)$ reflects the significant dependence of the relative performance of cultivars on environmental factors. However, such divergent conditions may be very useful for investigations of differences in grain nutrient concentrations between cultivars.

A considerable genotypic variation, both in grain yield and GNC, was observed during both seasons (fig 1a, b). There was no significant negative correlation between grain yield and GNC (the correlation coefficients were +0.26 and -0.44 during the dry and rainy season, respectively). Remarkably, in contrast to cultivars 10 and 12 (Pi hybrid 6181 and $\mathrm{CP}$ hybrid), cultivars 8 and 9 (KUH 2301 and KUH 2602) were able to combine high grain yield and high GNC.
During the dry season, KUH 2301 and $\mathrm{KUH}$ 2602 outyielded most of the low GNC varieties despite their especially high GNC. During the rainy season, when a greater range of grain yields was observed, only the low yielding cultivars 3 and 7 (Thai $\mathrm{O}_{2}$ Comp \#3 and Guatemala DMR) showed a higher GNC. While Thai $\mathrm{O}_{2}$ Comp \#3 continued to show a high GNC during the dry season, Guatemala DMR only had an average GNC.

$G P C$ values ranged from 0.24 to $0.28 \%$ during the dry season and from 0.12 to $0.18 \%$ during the rainy season (fig 1c, d). The cultivars 8 , 9,10 and 12 were selected for closer examination of the relative accumulation of phosphorus in the grain because they showed peculiarities in the combination of grain yield and GNC. Figures $1 \mathrm{c}$ and $1 \mathrm{~d}$ show differences between these cultivars in GPC, similar to those in GNC: the cultivars 8 and 9 also showed a higher GPC. The $G P C$ of cultivar 3 gives further clues as to the relationship between GNC and GPC. This cultivar reached high levels in GNC and GPC during both seasons. Grain yield and GPC were not significantly correlated ( $r=-0.22$ for the dry season and $r=-0.09$ for the rainy season). In comparison with the rainy season, genotypic variation in GKC was low during the dry season (fig $1 e, f)$. During the rainy season, the $G K C$ of cultivars 10 and 12 was lower than that of cultivars 3,8 and 9 . Surprisingly, the situation was almost reversed during the dry season. The differences between the mentioned varieties had vanished, and cultivar 12, which had a low GKC during the rainy season, achieved a high GKC during the dry season. Significant correlations between grain yield and GKC were not found $(r=-0.14$ for the dry season and $r=+0.04$ for the rainy season).

The similarities between GNC, GPC and, to a lesser extent, $G K C$ are reflected by predominantly positive correlations between these traits (table II). In some cases, the relationships between grain nutrient concentrations were relatively close (fig 2 a-f). In figure 2a where GNC is plotted against $G P C$, the positions of cultivars 4 and 8 (Thai Comp \#3 and KUH 2301) seem to be somewhat unusual: Thai Comp \#3 had a high GPC and a rather low GNC, and KUH 2301 combined a medium GPC and a high GNC. However, during the rainy season, these deviations were smaller (Thai Comp \#3) or vanished completely (KUH 2301). The lack of clearly identified "positive" correlation breakers (high GNC and low GPC) indicates that it is difficult, or even 

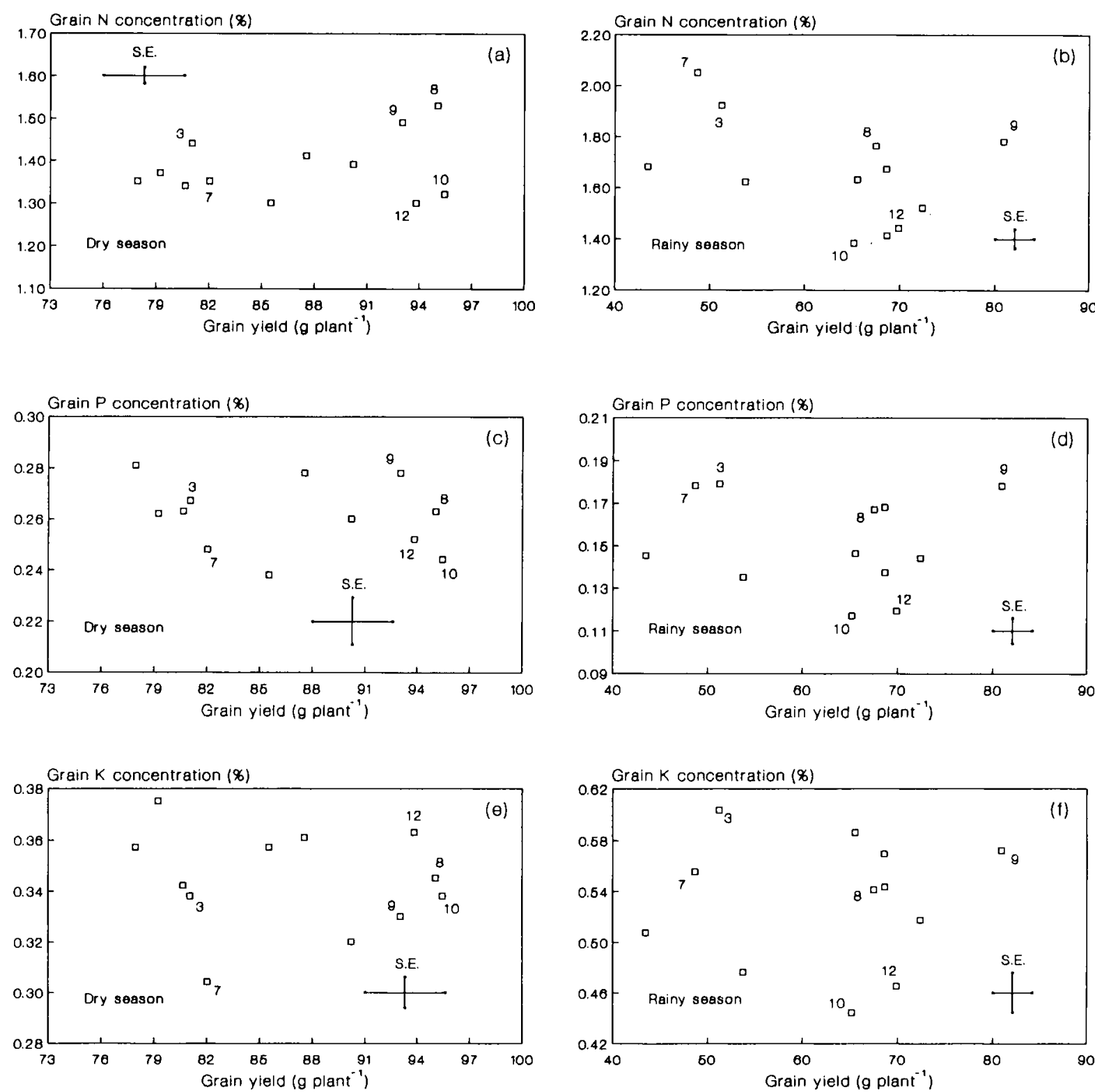

Fig 1. Grain yields of 12 tropical maize cultivars plotted against grain $N$ (a and $b$ ), $P$ (c and d) and $K$ (e and $f$ ) concentrations during the dry $(a, c, e)$ or the rainy $(b, d, f)$ season $\left(3=\right.$ Thai $O_{2}$ Comp $\# 3 ; 7=$ Guatemala DMR; $8=K U H ~ 2301 ; 9=K U H ~ 2602 ; 10=P i$ hybrid $6181 ; 12=\mathrm{CP}$ hybrid; other cultivars are without numbers). $\mathrm{SE}=$ standard error of a value.

Table II. Correlation between grain nitrogen (GNC), grain phosphorus (GPC) and grain potassium (GKC) concentration of 12 maize cultivars.

\section{GPC $\quad G K C$}

Rainy season

$\begin{array}{lll}\text { GNC } & +0.89^{*} & +0.64^{*} \\ \text { GPC } & & +0.83^{*} \\ \text { Dry season } & & \\ \text { GNC } & +0.57 & -0.19 \\ \text { GPC } & & +0.16\end{array}$

* Significant at the 0.05 probability level.
Table III. Correlations between nutrient uptake/nutrient harvest index and grain nutrient concentrations of 12 maize cultivars.

\begin{tabular}{llll}
\hline & & $\begin{array}{c}\text { Rainy } \\
\text { season }\end{array}$ & $\begin{array}{c}\text { Dry } \\
\text { season }\end{array}$ \\
\hline Total N uptake & GNC & +0.23 & $+0.76^{*}$ \\
Total P uptake & GPC & $+0.61^{*}$ & +0.12 \\
Total K uptake & GKC & +0.41 & $+0.61^{*}$ \\
& & & \\
N harvest index & GNC & +0.08 & +0.33 \\
P harvest index & $G P C$ & +0.31 & +0.16 \\
K harvest index & $G K C$ & +0.41 & -0.02 \\
& & & \\
\hline
\end{tabular}

GNC/GPC/GKC = grain; N/P/K : concentration. * Significant at the 0.05 probability level. 

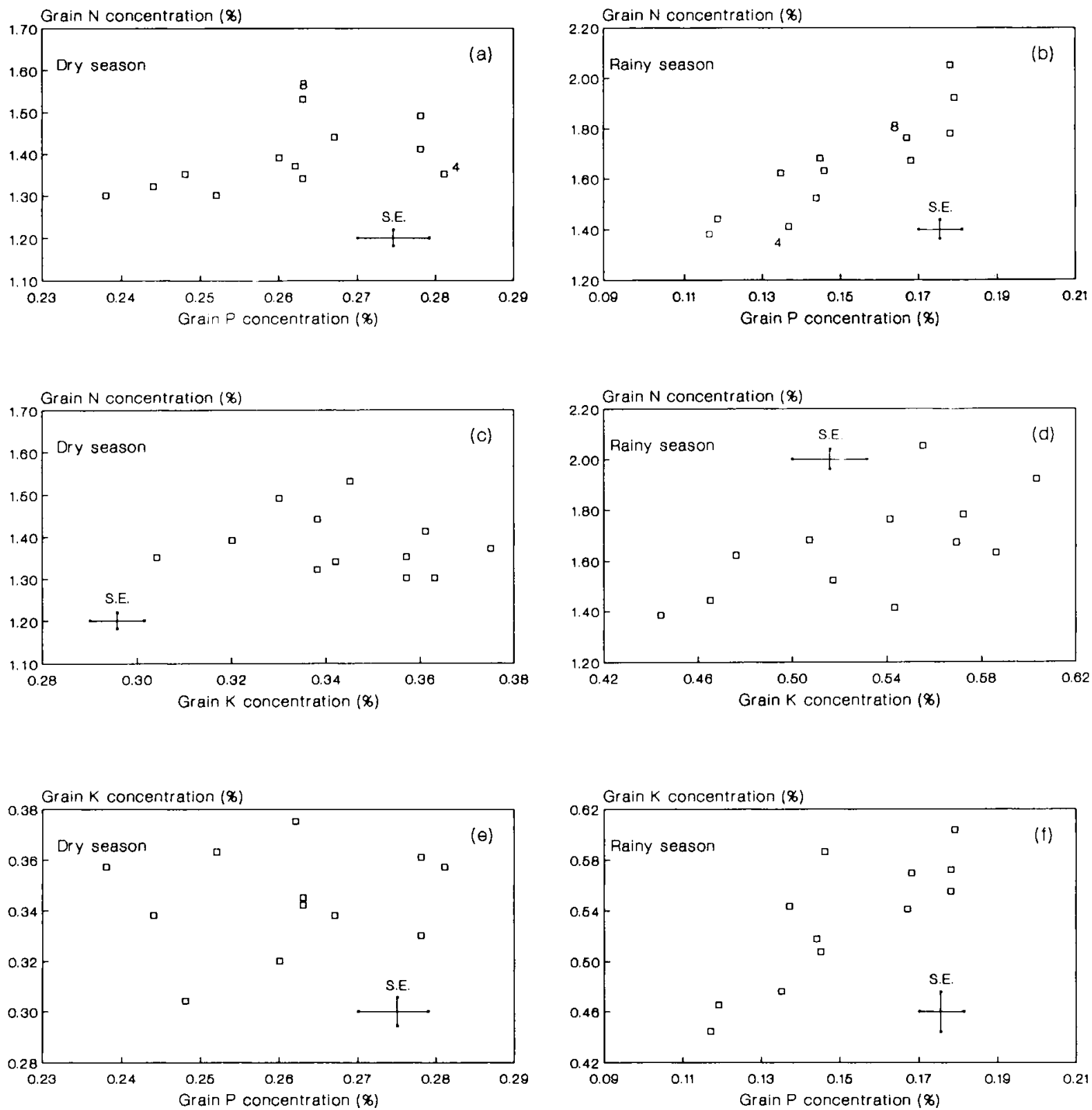

Fig 2. Grain $P$ and $K$ concentrations of 12 tropical maize cultivars during rainy $(b, d, f)$ and dry $(a, c, \theta)$ season plotted against grain $\mathrm{N}$ (a-d) and $\mathrm{K}(\mathrm{e}-\mathrm{f})$ concentrations $(4=$ Thai Comp \#3; $8=\mathrm{KUH} 2301$; other cultivars are without numbers). SE = standard error of a value.

impossible, to select simultaneously for high GNC and low GPC.

Although the differences between the high yielding cultivars KUH 2301, KUH 2602, Pi hybrid 6181 and the CP hybrid remained almost unaffected by the extremely different growing conditions during the 2 seasons, the correlations between the grain nutrient concentrations of the cropping seasons were not significant $(r=+$ $0.51,+0.39$ and +0.14 for GNC, GPC and GKC respectively). However, after exclusion of the only old local cultivar (cultivar. 7, Guatemala DMR), the correlation coefficient for GNC increased to $+0.74^{*}$ (fig 3a). This indicates that varietal differences in GNC were rather constant even under extremely contrasting. growing conditions.

Again Guatemala DMR (7) and, additionally, the cultivars 1 and 4 (Suwan I and Thai Comp \#3) were responsible for the weak correlation between the GPC of the rainy and the dry season (fig 3b).

In principle, there are 2 ways of increasing grain nutrient concentrations:

- by enhancing the nutrient uptake; and

- by improving the partitioning efficiency.

The utilization of already assimilated nutrients can be expressed by nutrient harvest indices which are defined as the proportion of grain nu- 

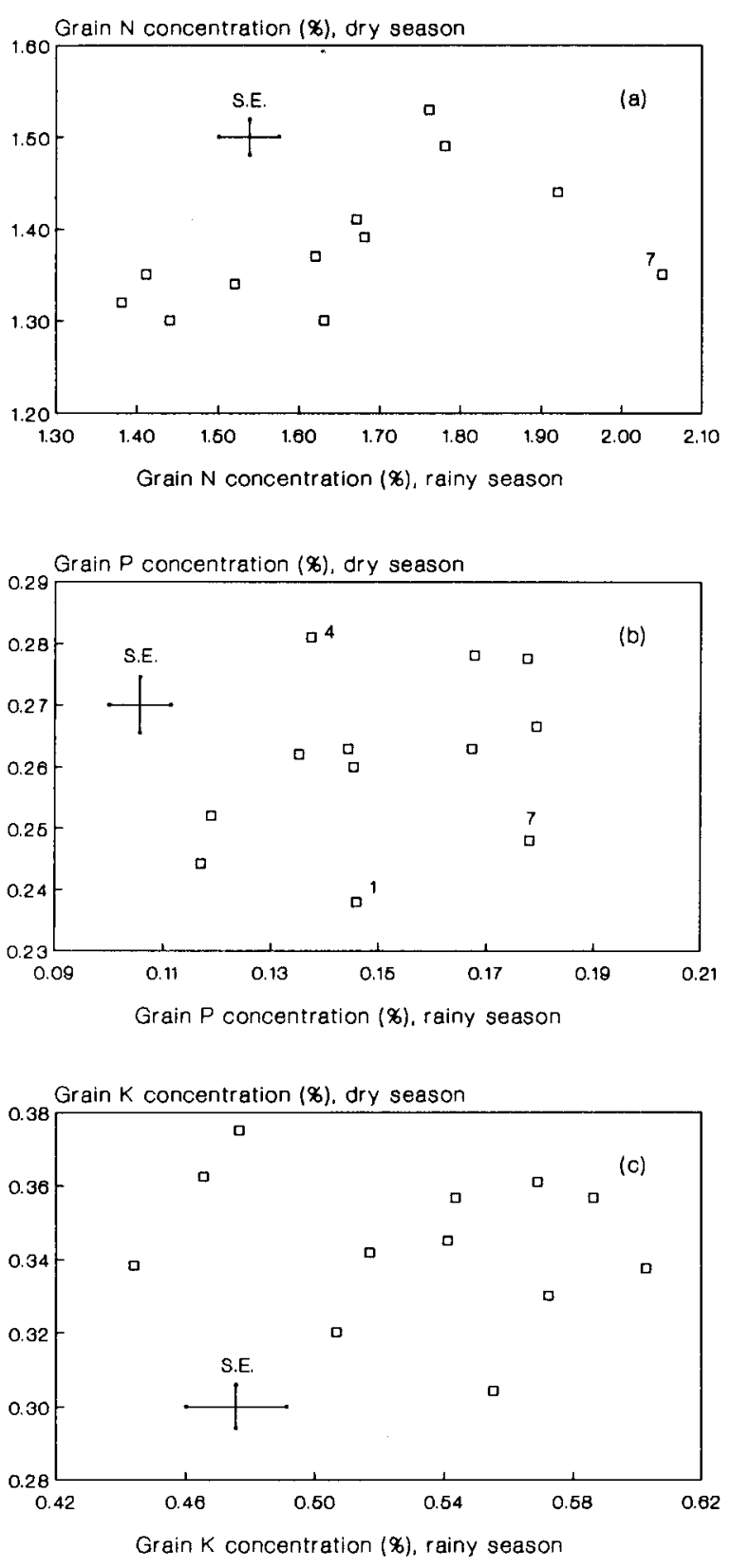

Fig 3. Grain $N, P$ and $K$ concentration of 12 tropical maize cultivars during rainy season plotted against grain $N(a), P$ (b) and $\mathrm{K}$ (c) concentrations during the dry season (1 = Suwan I; 4 = Thai Comp \#3; 7 = Guatemala DMR; other cultivars are without numbers). SE = standard error of a value.

trients to total plant nutrients. From table III it can be deduced that varietal differences in grain nutrient concentrations are neither totally explainable by differences in nutrient uptake nor by different nutrient harvest indices. However, in most cases, correlation coefficients of nutrient uptake were higher. Consequently, higher concentrations of nutrients in the grain were mainly the result of higher nutrient uptake; more efficient utilization of already incorporated nutrients played only a minor role.
According to Kramer (1979), the well known negative correlation between grain yield and GNC in wheat can be overcome by avoiding onesided breeding for higher harvest indices. Table IV indicates that the lack of a clear negative correlation between grain yield and GNC in this set of maize cultivars may actually be due to differences in biomass between genotypes, as high biomasses were generally associated with high total nutrient uptake. In contrast, the correlation coefficients between harvest index and total nutrient uptake were also positive (exception: $\mathrm{K}$ uptake during the rainy season) but generally lower. This may support the hypothesis that increases in grain yield may preferably be attained by increasing biomass if the GNC is to remain at an acceptable level. On the other hand, there was no consistently significant positive correlation between biomass and GNC, indicating that biomass-induced increases in $\mathrm{N}$ uptake were just high enough to prevent the dilution of kernel $\mathrm{N}$ caused by simultaneously increasing grain yields (the correlations between grain yield and biomass were $+0.73^{*}$ during the dry season and $+0.93^{*}$ during the rainy season, respectively).

\section{DISCUSSION}

Due to the poor quality of maize protein and the ready availability of inexpensive, high quality protein supplements such as soybeans, attempts to achieve an increase in protein content have not interested breeders to any great extent. Nevertheless, this should not discourage breeders from selecting high protein types because:

- maize protein can be utilized by ruminants such as bovines without any restriction;

- in many regions of the world additional sources of protein are not available;

- high protein cultivars may have at least slightly increased concentrations of lysine and tryptophan; and

- there is obviously no close inverse relationship between GNC and grain yield.

In this study, the cultivars $\mathrm{KUH} 2301$ and $\mathrm{KUH}$ 2602 were identified as high yielding, high protein cultivars. This indicates that a considerable variability in GNC in high yielding tropical maize hybrids exists. However, information concerning the lysine content is also needed if the outstanding nutritional value of the mentioned cultivars is to be confirmed. There are, however, clues that 
Table IV. Correlations between biomass/harvest index and total nutrient uptake/grain nutrient concentration of 12 maize cultivars.

$\begin{array}{cccccc}\text { Total } & \text { Total } & \text { Total } & \text { Grain } N & \text { Grain } P & \text { Grain K } \\ N \text { uptake } & P \text { Uptake } & \text { Kuptake } & \text { (\%) } & \text { (\%) } & (\%)\end{array}$

\begin{tabular}{lllllll}
\hline $\begin{array}{llllll}\text { Rainy season } \\
\text { Biomass }\end{array}$ & $+0.83^{*}$ & $+0.64^{*}$ & $+0.94^{*}$ & -0.32 & -0.04 & +0.15 \\
$\begin{array}{l}\text { Harvest index } \\
\text { Dry season }\end{array}$ & +0.31 & +0.50 & +0.45 & -0.04 & -0.31 & -0.44 \\
Biomass & & & & & & \\
Harvest index & $+0.73^{*}$ & $+0.70^{*}$ & +0.35 & +0.35 & -0.02 & +0.11 \\
& +0.28 & +0.24 & $-0.81^{*}$ & -0.48 & -0.13 & -0.09 \\
\hline
\end{tabular}

* Significant at the 0.05 probability level.

high levels of lysine are associated with high percentages of N. Arnold et al (1977) considered grain protein concentration of cultivars to be the best selection criterion for lysine concentration.

The literature offers contradictory information concerning correlations between grain yield and protein concentration. However, this and several other investigations indicate that gains in the percentage of protein can be realized without a decrease in grain yield. Such inverse relationship may occur but it seems that they are bound to extreme conditions. For instance, a weak negative correlation between grain yield and GNC was detected in the rainy season trial which may be due to the very wide range of yields. Another example is provided by the experiments of Dudley et al (1977) who found a high negative correlation between grain yield and percentage of protein $(r=-$ 0.70 ) in a set containing types with extremely high and extremely low protein values.

However, inverse relationships between GNC and grain yield will probably become more important if:

- cultivars with extremely high levels of $\mathrm{N}$ and therefore high requirements for $\mathrm{N}$ are grown;

- availability of nitrogen is limited;

- future increases in yield would predominantly be the result of breeding for an increased harvest index.

According to Kramer (1979), the last mentioned point could be responsible for the well documented negative correlation between grain yield and GNC in wheat (Kibite and Evans, 1984; Paccaud et al, 1985). Comparisons between old and modern wheat varieties have revealed that up to now, increases in yield are based almost exclu- sively on an improvement of the harvest index (Austin et al, 1980, 1989; Feil and Geisler, 1988). This does not seem always to be the case for maize (Jain et al, 1976; Stamp and Kullmann, 1984; Tollenaar, 1989). At least in 1 case, harvest index was even negatively correlated with grain yield (Jain et al, 1976). In our experiments, both harvest index and biomass contributed to higher grain yields. However, in both seasons only biomass showed a close relationship with nitrogen uptake. This supports the hypothesis that the non-existence of an inverse relationship between grain yield and GNC in maize is due to the breeding strategy which is different for wheat. In accordance with Bruetsch and Estes (1976), a considerable genotypic variation in GPC and GKC was observed. With the exception of $K$ during the rainy season, the relative accumulation of $P$ and $K$ in the grains was similar to $\mathrm{N}$ which was expressed by more or less positive correlations between GNC, GPC and GKC (table II). Comparable relationships between grain nutrient concentrations were found by $\mathrm{Ar}$ nold and Baumann (1976) and Arnold et al (1977).

Low activities of leaf nitrate reductase or protease may limit $\mathbf{N}$ enrichment in kernels (Deckard et al, 1973; Boyat and Robin, 1977; Reed et al, 1980; Eichelberger et al, 1989). However, if genotypic variation in GNC is really based on the different activity of these enzymes, it is difficult to explain how different activities of nitrate reductase or proteases should induce simultaneous increases in GPC and $G K C$, respectively. Perhaps high activities of those enzymes enhance the storing capacity for $P$ and $K$ by accumulation of proteins in grains. 
Alternatively, one may speculate that enzyme activities do not limit GNC and that phosphorus itself is somehow involved in the protein storing process.

Fortunately, the literature offers some clues as to the physiological background of positive correlations between GNC, GPC and GKC. In wheat, O'Dell et al (1972) found that $87 \%$ of the total grain phytate was associated with the aleurone layer. In some legume species, EDX (energy dispersive $X$-ray) analysis revealed that phytates seem to be present throughout the proteinaceous matrix portions of protein bodies (Lott and Buttrose, 1977). For Jennings and Morton (1963), there was little doubt that such protein bodies are the sites of accumulation of storage protein. Furthermore, Morris et al (1985) found that there was much similarity in the mobilisation of both leaf $\mathbf{N}$ and $\mathrm{P}$. This may indicate that there is a physiological linkage between nitrogen and phosphorus uptake of grains and that it will be very difficult or even impossible to decouple GNC and GPC completely. These arguments are strongly supported by figure $2 a-b$ which reveals a rather close relationship between GNC and GPC. A similar positive correlation was found by Arnold et al (1977). However, further investigations in different environments and with other cultivars are needed to confirm the close linkage between GNC and GPC.

Phytate is the main storage form of $P$ in cereals. As a salt of the hexainositol phosphoric acid, it is a carrier of cations. Therefore, increases in grain phosphorus may inevitably lead to considerably higher concentrations of $\mathrm{K}, \mathrm{Mg}$ or $\mathrm{Ca}$. This would explain the positive correlation between $G P C$ and $G K C$ during the rainy season and between GPC and grain magnesium content in the experiment of Arnold and Baumann (1976). However, the lack of a comparable correlation during the dry season suggests that other factors also influence GKC.

Finally, the economical importance of the varietal differences in GPC and GKC will be considered more closely. For example, if the grain is sold, cultivation of CP hybrid instead of KUH 2301 would have saved $15 \%$ of the $P$ and $5 \%$ of the $\mathrm{K}$ export from the field, taken as an average of both seasons. However, this gain would have been paid for by a considerable loss in nitrogen yield, which is in any case, negligible for Thai cash crop farmers.

\section{ACKNOWLEDGMENTS}

The authors wish to thank $R$ Tangadulratana and $S$ Changsalak for their valuable assistance. This investigation was supported by the GTZ.

\section{REFERENCES}

Arnold JM, Baumann LF (1976) Inheritance of and interrelationships among maize kernel traits and elemental contents. Crop Sci 16, 439-440

Arnold JM, Bauman LF, Aycok HS (1977) Interrelations among protein, lysine, oil, certain mineral element concentrations, and physical kernel characteristics in two maize populations. Crop Sci 17, 421425

Austin RB, Bingham J, Blackwell RD, Evans LT, Ford M, Morgan CL, Taylor M (1980) Genetic improvements in winter wheat yields since 1900 and asso. ciated physiological changes. J Agric Sci Camb 94, 675-689

Austin RB, Ford MA, Morgan CL (1989) Genetic improvement in the yield of winter wheat: a further evaluation. J Agric Sci Camb 112, 295-301

Boyat A, Robin P (1977) Relations entre productivité, qualité du grain et activité nitrate réductase chez les céréales. Ann Amélior Plant 27, 389-410

Boyat A, Kaan F, Panouillé A, Rautou S (1979) Amélioration du maïs pour la teneur en protéines du grain. In: Seed Protein Improvement in Cereals and Grain Legumes. Vol II. Int Atomic Energy Agency, Vienna, 151-164

Boyat A, Derieux M, Kaan F, Rautou S (1980) Maize breeding for improvement of kernel protein content using Illinois high protein population. In: Improvement of Quality Traits of Maize for Grain and Silage Use (Pollmer WG, Phipps RH, eds) Martinus Nijhoff Publ bv, The Hague, 173-183

Bruetsch TF, Estes GO (1976) Genotype variation in nutrient uptake effiency in corn. Agron $J 68,521$ 523

Deckard EL, Lambert RJ, Hageman RH (1973) Nitrate reductase activity in corn leaves as related to yields of grain and grain protein. Crop Sci 13, 343-350

Dudley JW, Lambert RJ, de la Roche IA (1977) Genetic analysis of crosses among com strains divergently selected for percent oil and protein. Crop Sci 17, 111-117

Eberhard D (1977) Untersuchungen über den Einfluß von proteinreichen Inzuchtlinien auf die Ertragsgestaltung von Hybriden unter dem Aspekt der Körnerund Silonutzung von Mais (Zea mays $\mathrm{L}$ ). Ph D Thesis, Hohenheim

Eichelberger KD, Lamber RJ, Below FE, Hageman RH (1989) Divergent phenotypic recurrent selection for nitrate reductase activity in maize. II. Efficient use of fertilizer nitrogen. Crop Sci 29, 1398-1402 
Feil B, Geisler G (1988) Untersuchungen zur Bildung und Verteilung der Biomasse bei alten und neuen deutschen Sommerweizensorten. J Agron Crop Sci $161,148-156$

Glover DV, Mertz ET (1987) Corn. In: Nutritional Quality of Cereal Grains: Genetic and Agronomic $1 \mathrm{~m}$ provement (Olson RA, Frey KJ, eds) Agronomy 28, 183-336

Gupta D, Kovacs I, Gaspar L (1975) Protein quality traits and their relationships with yield and yield components of opaque-2 and analogous normal hybrids and inbred lines. Theor Appl Genet 45, 341348

Jain HK, Mukherjee BK, Singh RD, Agrawal KN (1976) The present basis and future possibilities of breeding for yield in maize. Z Pflanzensuecht 76, 90-101

Jennings AC, Morton RK (1963) Amino acids and protein synthesis in developing wheat endosperm. Aust J Biol Sci 16, 384-394

Kauffman KD, Dudley JW (1979) Selection indices for grain yield, percent protein, and kernel weight. Crop Sci 19, 583-588

Kibite S, Evans LE (1984) Causes of negative correlations between grain yield and grain protein concentration in common wheat. Euphytica 33, 801-810

Kramer T (1979) Environmental and genetic variation for protein content in winter wheat (Triticum aestivum L). Euphytica 28, 209-218

Lott JNA, Buttrose MS (1977) Globoids in protein bodies of legume seeds cotyledons. Aust J Plant Physiol $5,89-111$
Maga JA (1982) Phytate: its chemistry, occurrence, food interactions, nutritional significance, and methods of analysis. J Agric Food Chem 30, 1-9

Michael B, Zink F, Lantzsch HJ (1980) Effect of phosphate application on phytin-phosphorus and other phosphate fractions in developing wheat grains. Z Pflanzenernaehr Bodenkd 143, 377-384

Morris F, Flynn VJ, Reilly ML (1985) Nitrogen and phosphorus mobilisation in maturing/senescing wheat flag leaves. Field Crops Res 12, 71-80

O'Dell BL, de Boland AR, Koirtyohann SR (1972) Distribution of phytate and nutritionally important elements among the morphological components of cereal grains. J Agric Food Chem 20, 718-721

Paccaud FX, Fossati A, Hong Sheng Cao (1985) Breeding for yield and quality in winter wheat: consequences for nitrogen uptake and partitioning effiency. Z Pflanzensuecht 94, 89-100

Reed AJ, Below FE, Hageman RH (1980) Grain protein accumulation and the relationship between leaf nitrate reductase and protease activities during grain development in maize (Zea mays L). Plant Physiol 66, 164-170

Stamp P, Kullmann A (1984) Shoot growth, green leaf area development and NAR of maize. Comparison between cultivars grown in Germany 1875 and 1976. Maydica XXIX, 235-246

Tollenaar M (1989) Genetic improvement in grain yield of commercial maize hybrids grown in Ontario from 1959 to 1988. Crop Sci 29, 1365-1371 